\title{
Luminescence dating of Pleistocene alluvial sediments affected by the Alhama de Murcia fault (eastern Betics, Spain) - a comparison between OSL, IRSL and post-IR IRSL ages
}

\author{
REZA SOHBATI, ANDREW S. MURRAY, JAN-PIETER BUYLAERT, MARIA ORTUÑO, PEDRO P. CUNHA AND \\ EULÀLIA MASANA
}

BOREAS

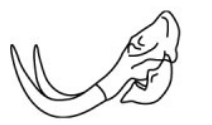

\begin{abstract}
Sohbati, R., Murray, A. S., Buylaert, J.-P., Ortuño, M., Cunha, P. P. \& Masana, E. 2012 (April): Luminescence dating of Pleistocene alluvial sediments affected by the Alhama de Murcia fault (eastern Betics, Spain) - a comparison between OSL, IRSL and post-IR IRSL ages. Boreas, Vol. 41, pp. 250-262. 10.1111/j.15023885.2011.00230.x. ISSN 0300-9483.

The ages of nine alluvial units, identified by the integration of data obtained from five trenches at the southern termination of the Alhama de Murcia Fault (AMF) (eastern Betics, Spain), are constrained using luminescence dating based on the Optically Stimulated Luminescence (OSL) from quartz, Infrared Stimulated Luminescence (IRSL) at $50^{\circ} \mathrm{C}$, and post-IR elevated temperature $\left(225^{\circ} \mathrm{C}\right)$ IRSL signals from K-feldspar. All signals pass the routine tests associated with the Single Aliquot Regenerative (SAR) protocol, including the recycling ratio, recuperation, and dose recovery tests. The equivalent doses $\left(D_{e}\right)$, residual doses and anomalous fading rates ('g'-values) of the IRSL at $50^{\circ} \mathrm{C}\left(\mathrm{IR}_{50}\right.$ ) and post-IR IRSL at $225^{\circ} \mathrm{C}$ (pIRIR 225 ) from K-feldspar are compared for 16 samples. The residual doses in laboratory-bleached samples suggest that there is no significant unbleachable residual dose using these signals; the residual doses are $0.17 \pm 0.15 \mathrm{~Gy}$ and $0.93 \pm 0.80 \mathrm{~Gy}$, respectively. For both signals, the residual doses appear to depend on the corresponding natural doses; that is, the larger the natural doses, the larger the residuals, an observation made for the first time for IRSL signals. The average fading rate for the pIRIR $225(0.94 \pm 0.07 \% /$ decade, $n=48)$ is markedly lower than that for $\operatorname{IR}_{50}(2.08 \pm 0.16 \% /$ decade, $n=48)$, indicating that the age correction for the pIRIR 225 is much smaller than that for $\operatorname{IR}_{50}$. The agreement between the quartz OSL, corrected $\mathrm{IR}_{50}$, and corrected $\mathrm{pIRIR}_{225}$ for the two youngest samples suggests that the pIRIR $\operatorname{Is}_{22}$ is an accurate dating signal in this age range $(<25 \mathrm{ka})$. The oldest age obtained using the corrected pIRIR 225 signal is $320 \pm 20 \mathrm{ka}$ for sample 098807 ; the corrected $\mathrm{IR}_{50}$ age is only $154 \pm 15 \mathrm{ka}$. Although this suggests that the pIRIR 225 signal circumvents the effect of anomalous fading to a great extent, the resulting age cannot be regarded as necessarily accurate because of the limitations of the fading correction model used, and the absence of independent age control for the old samples. Nevertheless, our luminescence ages provide the first age constraints on the seismic activity of the southern termination of the AMF.
\end{abstract}

Reza Sohbati (e-mail: resih@risoe.dtu.dk) and Andrew S. Murray, Nordic Laboratory for Luminescence Dating, Department of Geoscience, Aarhus University, Risø DTU, DK-4000 Roskilde, Denmark; Jan-Pieter Buylaert, Nordic Laboratory for Luminescence Dating, Department of Geoscience, Aarhus University, Risø DTU, DK-4000 Roskilde, Denmark and Radiation Research Division, Riso National Laboratory for Sustainable Energy, Technical University of Denmark, DK-4000, Roskilde, Denmark; Maria Ortuño, Department of Geodynamics and Geophysics, University of Barcelona, Zona Universitaria de Pedralbes, 08028 Barcelona, Spain (present address: Geosciences Centre, National Autonomous University of Mexico, Juriquilla, Queretaro, 76230, Mexico); Pedro P. Cunha, Department of Earth Sciences, IMAR-Marine and Environmental Research Centre, University of Coimbra, Largo Marquês de Pombal, 3000-272 Coimbra, Portugal; Eulàlia Masana, Department of Geodynamics and Geophysics, University of Barcelona, Zona Universitaria de Pedralbes, 08028 Barcelona, Spain; received 6th April 2011, accepted 6th September 2011.
It is notoriously difficult to quantify the time evolution of tectonic activity, because there is an absence of suitable material for dating. Luminescence dating is one of the few methods generally applicable to this class of problem. This study describes the application of luminescence dating to the active tectonic setting of the eastern Betics, Spain. This area is dominated by lithospheric shortening; the slow convergence rate (4.5$5.6 \mathrm{~mm} \mathrm{a}^{-1}$ ) of the African and Iberian plates is accommodated by a number of active faults, which do not have reliable records of seismicity owing to their low slip rates and the long recurrence intervals between earthquakes (Masana et al. 2004 and references therein).

The Alhama de Murcia fault (AMF) is one of these low-slip-rate faults, extending $\sim 100 \mathrm{~km}$ from the
Huercal-Overa depression in the SW to the surroundings of Murcia in the NE (Fig. 1). Although the Quaternary activity of this fault has been described in its northeastern and central segments (e.g. Silva 1994; Silva et al. 1997, 2003; Martínez-Díaz 1998; MartínezDíaz et al. 2001, 2003; Masana et al. 2004, 2005), there is no reliable information on its southwestern termination, and no overall chronology has been developed.

In the southern Guadalentin basin (eastern Betics, Spain), several alluvial fan phases have been deformed by the activity of the AMF (Fig. 1). Thus by establishing a chronology for these alluvial deposits we can derive crucial information on the dynamics and palaeoseismology of this fault; such information is important to a seismic hazard assessment in the region. 
Fig. 1. Study area in the eastern Betic Cordillera. The Alhama de Murcia fault (AMF) (SE Spain) and other main faults in the area are shown. $\mathrm{PF}=$ Palomares fault $; \mathrm{CF}=$ Crevillente fault. The main mountain ranges and cities are also shown. This figure is available in colour at http://www.boreas.dk.

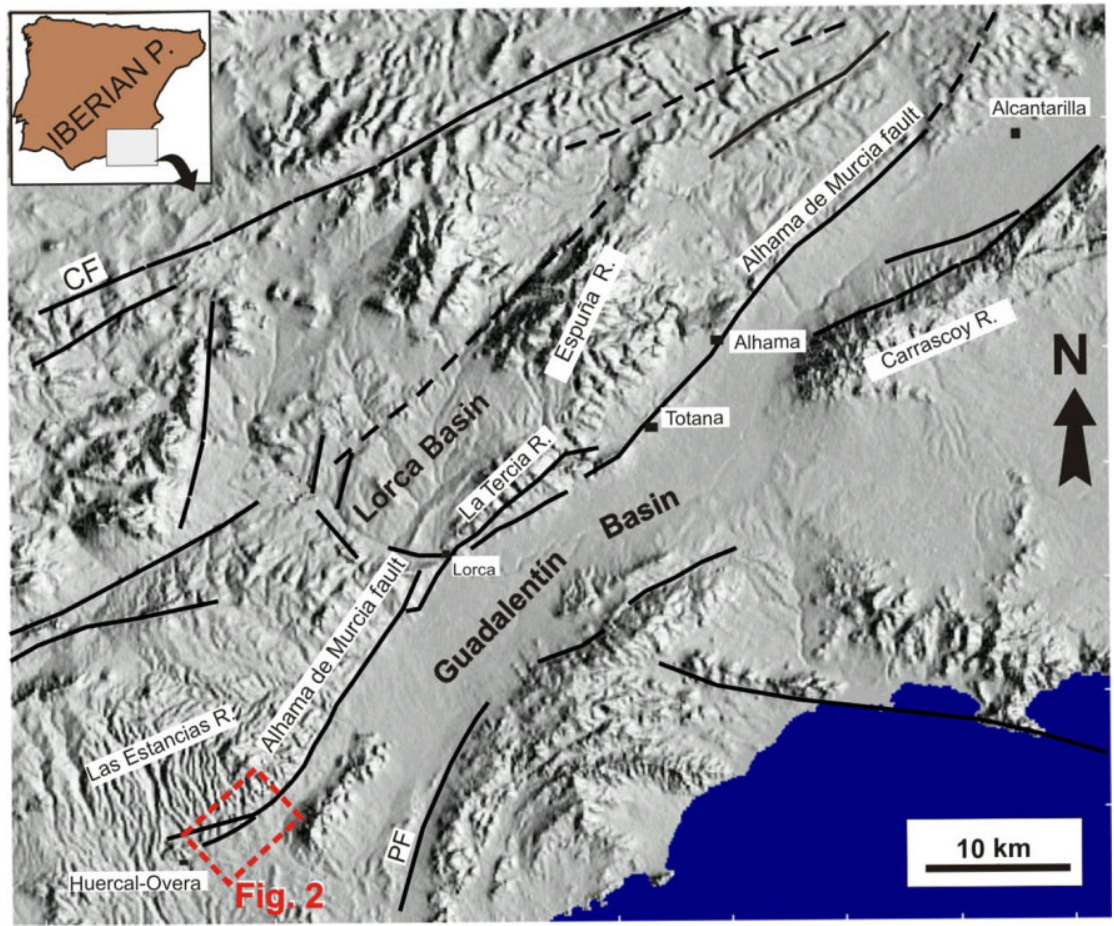

Luminescence dating has been widely used to provide an absolute chronology in palaeoseismological investigations across the world. Many studies have been carried out in the Alpine-Himalayan seismic belt, stretching from the Mediterranean through the Middle East into Central Asia. In the Middle East, many studies have been conducted in Israel (Amit et al. 1996; Porat et al. 1997, 2009) and in Iran (Fattahi et al. 2006a, b, 2007, 2010; Le Dortz et al. 2009; Nazari et al. 2009). There have also been studies in Mongolia (Nissen et al. 2009), India (Mathew et al. 2006; Thakur et al. 2006), China (Yanchou et al. 2002; Chen et al. 2003a, b, 2009; Haibing et al. 2005), South Korea (Cheong et al. 2003), Australia (Crone et al. 2003; Quigley et al. 2006) and the USA (Berger et al. 2010).

Most of this research has used quartz as the luminescence dosimeter. As a result, the time range has been limited to the last $100 \mathrm{ka}$, because of the saturation of the quartz Optically Stimulated Luminescence (OSL) signal (e.g. Chen et al. 2003a, b). The few studies that have made use of feldspar have been restricted to a similar or even shorter time range because of the anomalous loss of the Infrared Stimulated Luminescence (IRSL) signal (e.g. Fattahi et al. 2007; Porat et al. 2009), although the extended dose response of feldspar should have allowed a correspondingly extended age range. However, for seismic activity with a low recurrence interval it is desirable to develop a chronology over a much longer period than was possible in these studies. Extending the age range and providing evidence for the long-term behaviour would provide a major improvement in our ability to assess the seismic hazard posed by such faults.

In the present study we take advantage of the recently proposed $\mathrm{K}$-feldspar post-IR IRSL signal at an elevated temperature of $225^{\circ} \mathrm{C}$ ( pIRIR $_{225}$ ) (Thomsen et al. 2008; Buylaert et al. 2009) to define the chronology of Pleistocene alluvial fan sediments affected by the southern termination of the AMF. The application of this signal allows us to extend the age of the datable sediments to $>200 \mathrm{ka}$ in a palaeoseismological study for the first time, thus providing evidence of the long-term behaviour of the AMF.

\section{Site description and sampling}

The AMF terminates in the SW in a splayed structure composed of three main branches that have blocked, folded and faulted the alluvial fans draining from the Las Estancias range in a complex manner. Figure 2 shows a detailed geological map of the alluvial phases based on the interpretation of the aerial photos and field survey. Sixteen samples were collected for OSL dating in five trenches excavated at various locations along the fault branches in the Goñar area. The sediments sampled have different source basins, but share a common drainage area. In all cases, the stratigraphical units comprise alluvial fan facies deposited by braided ephemeral streams and debris flows (Fig. 3). A detailed description of the stratigraphy and sedimentology of these trenches and of the local geological context is given in Ortuño et al. (in press). 


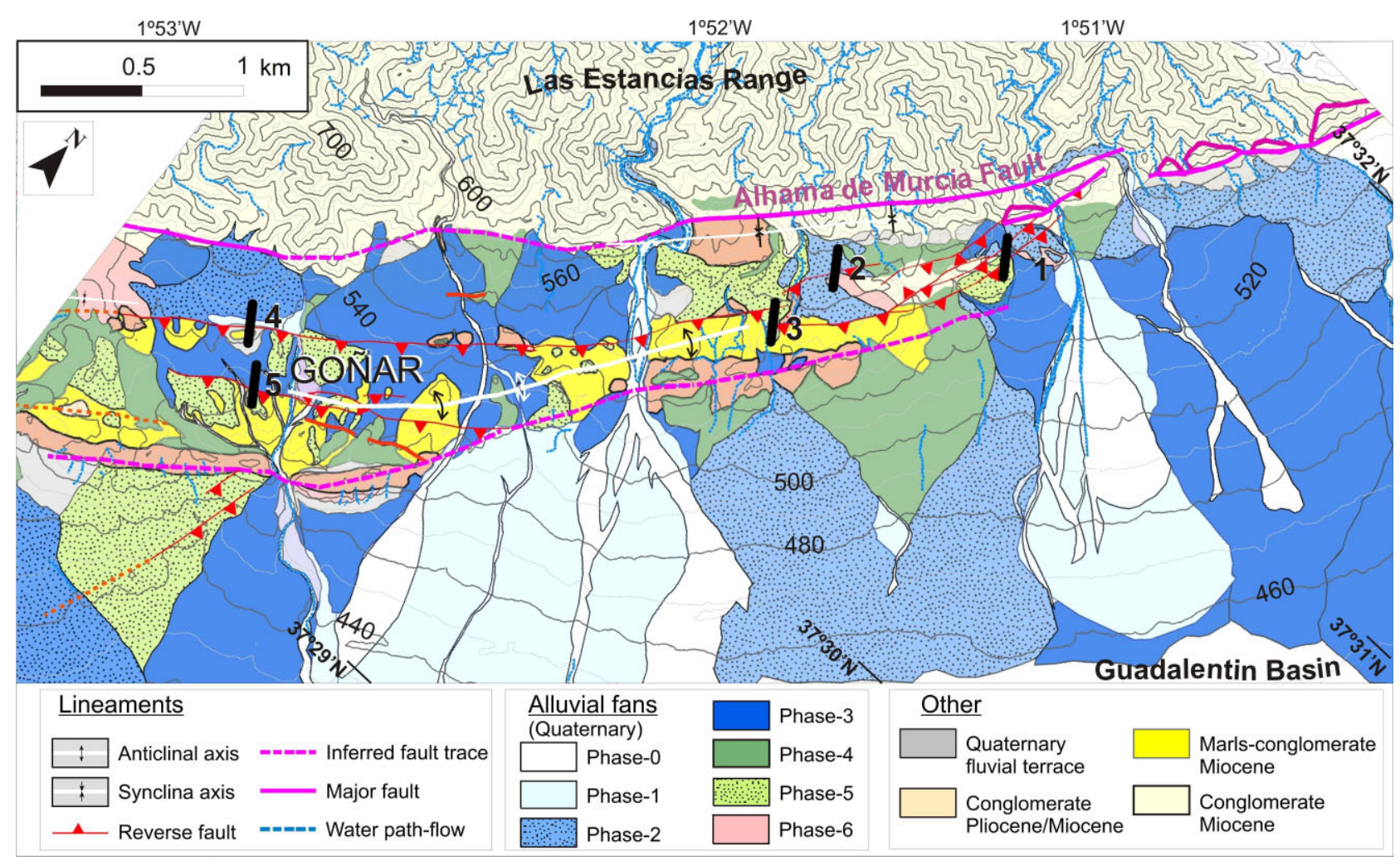

Fig. 2. Map of the main lithological units and tectonic structures in the study area. The locations of the five trenches excavated for paleoseismological investigation are shown as $1=$ Carrascos; $2=$ Gabarrones; $3=$ Tio Rey; $4=$ Sardinas; $5=$ Era. This figure is available in colour at http://www.boreas.dk.

Seven samples were collected by hammering steel tubes of $5-7 \mathrm{~cm}$ diameter into the wall of the trenches, while the remaining nine were taken at night (using weak illumination from hand-held red lights) and stored immediately in opaque plastic bags. The samples were selected in order to provide the maximum information on the timing of the accumulation of the various deposits and thus on the history of the earthquakes that ruptured or initiated these deposits. Each light-protected sample was accompanied by $350-500 \mathrm{~g}$ of similar material for watercontent and dose rate analysis. In all cases, the sampled sediment was coarse to fine sand or silt, with a high concentration of felsic minerals (mainly quartz).

\section{Sample preparation and measurement facilities}

The samples were processed using conventional methods. Wet-sieving was used to isolate the grain size range $180-250 \mu \mathrm{m}$. This fraction was then treated with $10 \% \mathrm{HCl}$ to remove carbonates, followed by $10 \% \mathrm{H}_{2} \mathrm{O}_{2}$ to remove any reactive organic material. The K-rich feldspar grains were separated by floating in heavy liquid $\left(\rho=2.58 \mathrm{~g} \mathrm{~cm}^{-3}\right)$. These grains were then etched using $10 \% \mathrm{HF}$ acid for $40 \mathrm{~min}$ to dissolve the alpha- irradiated surface layer and to remove surface weathering and coatings. Any fluoride contamination was removed using a $10 \% \mathrm{HCl}$ solution for $20 \mathrm{~min}$. A similar treatment was applied to extract quartz grains (the fraction $>2.62 \mathrm{~g} \mathrm{~cm}^{-3}$ was used), but using concentrated $(40 \%) \mathrm{HF}$ for $60 \mathrm{~min}$ followed by $10 \% \mathrm{HCl}$ for $40 \mathrm{~min}$ in the final two stages.

All luminescence measurements were made using a Risø TL/OSL reader (model TL-DA 20), with blue light stimulation $\left(\lambda=470 \mathrm{~nm}, \sim 80 \mathrm{~mW} \mathrm{~cm}^{-2}\right)$ and photon detection through a 7.5-mm Hoya U-340 glass filter for quartz, and infrared stimulation $(\lambda=875 \mathrm{~nm}$, $\sim 135 \mathrm{~mW} \mathrm{~cm}^{-2}$ ) and photon detection through a Schott BG39/Corning 7-59 filter combination (2 and $4 \mathrm{~mm}$, respectively) for K-feldspar. Beta irradiations used a ${ }^{90} \mathrm{Sr} /{ }^{90} \mathrm{Y}$ calibrated (for both discs and cups) source mounted on the reader (Bøtter-Jensen et al. 2010). Grains were mounted as large $(8 \mathrm{~mm}$ diameter for quartz) or small ( $2 \mathrm{~mm}$ diameter, containing about 100 grains of feldspar) aliquots in a monolayer using silicone oil on 10-mm-diameter stainless steel discs (quartz) or cups (feldspar). The heating rate was $5^{\circ} \mathrm{C} \mathrm{s}^{-1}$ throughout. All thermal treatments and stimulations at temperatures higher than $200^{\circ} \mathrm{C}$ were carried out in nitrogen atmosphere, and a pause of $10 \mathrm{~s}$ was inserted before stimulation to allow all grains to reach the measurement temperature. 



SE

Gabarrones trench wall SW (Fault branch 1)

NW SE

Carrascos-2 trench wall NE (Fault branch 2)

CARR-PC2

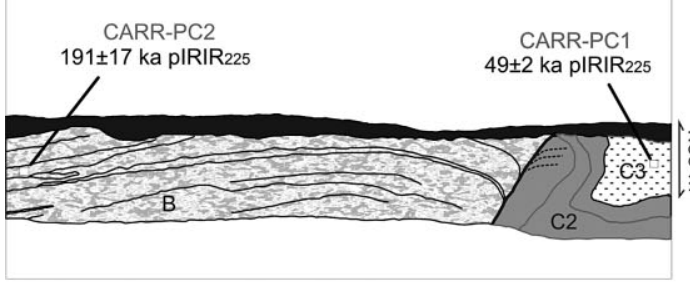
NW

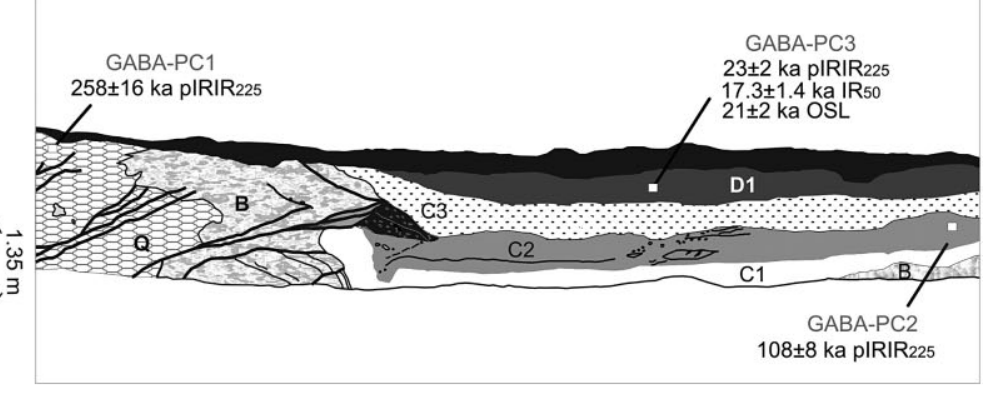

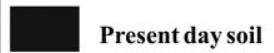

Regolith

D3 D2/D3 Dark brown matrix supported rounded heterometric conglomerate, composed of schists and minor quartzites, with sizes ranging between few millimeters and $5 \mathrm{~cm}$. Matrix made of sand and silt.

D1 D1 Brown matrix supported rounded heterometric conglomerate, composed of schists and minor quartzites, with sizes ranging between few millimeters and $10 \mathrm{~cm}$ Matrix made of sand and silt. Strongly affected by burrowing. c3 C Reddish matrix supported subangular heterometric conglomerate, with sparse calcification. Occasionally, the units have centimetric lenses of grain-supported C2 rounded conglomerates. Lithologies vary form schists, quartzites to minor marble. Sub-unit $\mathrm{C} 1$ and $\mathrm{C} 3$ have a

C1 high several calcrete levels, are pumpkin to white colored with clasts smaller than $3 \mathrm{~cm}$. Sub-unit $\mathrm{C} 2$ have a characteristic red to strong red coloration and clasts up to $15 \mathrm{~cm}$ diameter.

H $\quad \mathbf{H}$ White fine sand and silt with local lensoidal layers of fine size conglomerates.

B Grey sub-rounded grain-supported and layered homometric micro-conglomerate and conglomerates of silicate lithologies with predominant medium to fine grain sizes, locally coarse. In Gabarrones trench, the unit is locally matrix-supported.

Q $\mathrm{O}$ Grain supported hetermometric conglomerates made of quartz and schists subanular clasts of $<10 \mathrm{~cm}$ diameter. Grey coloration. many clasts are broken. A regolith has developed on top of this unit.
J Grain to matrix supported hetermometric conglomerate made of quartz and schists rounded clasts of $<10 \mathrm{~cm}$ diameter. Locally, high penetration of roots and developement of calcrete nodules. Light brown color.

$\mathbf{J} / \mathbf{P}$ Alternating beds of sub-rounded grain-

P3 supported homometric conglomerate and sandstone. The beds have cross lamination and range in thickness from 5 to $50 \mathrm{~cm}$. The conglomerates are heterogeneous and locally homogeneous, have grain sizes varying between $1-2 \mathrm{~mm}$ and $10-15 \mathrm{~cm}$ and are mainly made of silicates lithologies. The subunits are distinguished by the different coloration, from grey to brown and red.

Neogene basement Alternating marls and medium to fine well cemented marine conglomerate. Grey-yellow color. The conglomerates are subangular, grainsupported, rich in silicates pebbles and have a carbonatic matrix.

Fig. 3. Locations of samples in the trench profiles. The sedimentological features of each unit are provided. Fading-corrected pIRIR 225 ages are shown for all samples. For the two youngest samples, the ages determined using fading-corrected $\mathrm{IR}_{50}$ and quartz OSL signal are also reported (modified from Ortuño et al. in press). 


\section{Dosimetry}

Radionuclide concentrations $\left({ }^{238} \mathrm{U},{ }^{232} \mathrm{Th}\right.$ and $\left.{ }^{40} \mathrm{~K}\right)$ were measured using high-resolution gamma spectrometry. First, the additional sediment sample associated with the OSL sample was dried at $50^{\circ} \mathrm{C}$. A subsample of $\sim 250 \mathrm{~g}$ was pulverized and homogenized, and then heated to $450^{\circ} \mathrm{C}$ for $24 \mathrm{~h}$ to remove any organic matter. The material was then cast in wax to prevent radon loss and to provide a reproducible counting geometry. Samples were stored for at least three weeks to allow ${ }^{222} \mathrm{Rn}$ to reach equilibrium with its parent ${ }^{226} \mathrm{Ra}$ before being measured on a high-purity Germanium detector for at least $24 \mathrm{~h}$. Details of the gamma spectrometry calibration are given in Murray et al. (1987).

The external beta and gamma dose rate is the same to both quartz and $\mathrm{K}$-feldspar grains, but the internal beta dose rate to $\mathrm{K}$-feldspar grains makes up a significant portion of the total dose rate. This contribution is derived both from the structural potassium in the mineral and from minor amounts of internal ${ }^{87} \mathrm{Rb},{ }^{238} \mathrm{U}$ and ${ }^{232}$ Th (e.g. Mejdahl 1987). The internal beta dose rate activity from ${ }^{40} \mathrm{~K}$ was calculated based on an assumed effective potassium content of $12.5 \pm 0.5 \%$ (Huntley \& Baril 1997), and the beta contribution from ${ }^{87} \mathrm{Rb}$ was calculated assuming a ${ }^{87} \mathrm{Rb}$ content of $400 \pm 100$ ppm (Huntley \& Hancock 2001). A small internal alpha contribution of $0.10 \pm 0.05 \mathrm{~Gy} \mathrm{ka}^{-1}$ from internal ${ }^{238} \mathrm{U}$ and ${ }^{232} \mathrm{Th}$ was also included in the dose rates, derived from ${ }^{238} \mathrm{U}$ and ${ }^{232} \mathrm{Th}$ concentration measurements by Mejdahl (1987). For quartz, an internal dose rate of $0.06 \pm 0.03 \mathrm{~Gy} \mathrm{ka}^{-1}$ was assumed (Buylaert et al. 2008a). The radionuclide concentrations were converted to dose rate data using the conversion factors from Olley et al. (1996).

The contribution from cosmic radiation to the dose rate was calculated following Prescott \& Hutton (1994), assuming an uncertainty of $5 \%$. The long-term water content of each sample was estimated based on the field water content and saturation water content, but also on the probable position of the water table during the burial time. All radionuclide concentrations, water contents and dose rates are summarized in Table 1. The internal dose rate to the etched $\mathrm{K}$-feldspar grains is $\sim 26 \%$ of the total dose rate on average (16 samples), and the total $\mathrm{K}$-feldspar dose rate is $\sim 0.9 \mathrm{~Gy} \mathrm{ka}^{-1}$ higher than the total dose rate to etched quartz grains of the same size (Table 1).

\section{Luminescence characteristics}

\section{$O S L$}

As quartz OSL is the most widely used luminescence dating signal and its reliability for dose determination using a Single Aliquot Regenerative (SAR) protocol has been demonstrated (e.g. Murray \& Olley 2002), we

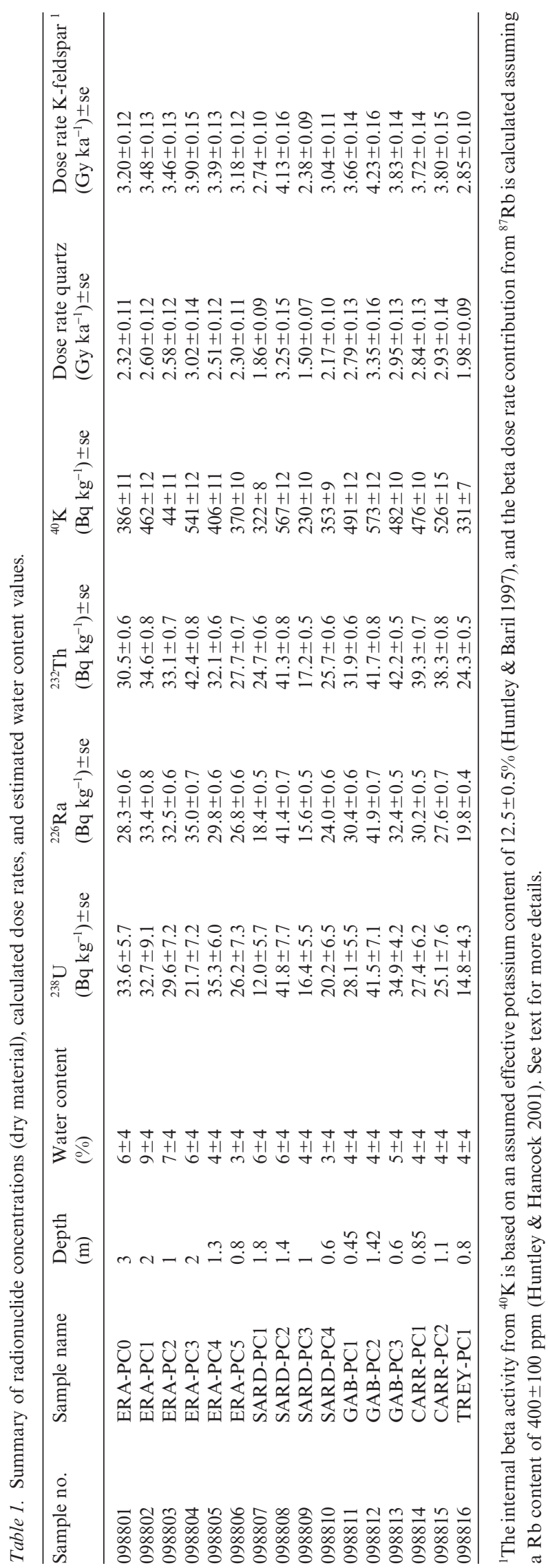


Table 2. Outline of the SAR OSL and post-IR IRSL protocols (Murray \& Wintle, 2003; Buylaert et al. 2009).

\begin{tabular}{|c|c|c|c|c|}
\hline \multirow[t]{2}{*}{ Step } & \multicolumn{2}{|l|}{ Quartz } & \multicolumn{2}{|l|}{ K-feldspar } \\
\hline & Treatment & Observed & Treatment & Observed \\
\hline 1 & Dose & & Dose & \\
\hline 2 & Preheat $\left(260^{\circ} \mathrm{C}\right.$ for $\left.10 \mathrm{~s}\right)$ & & Preheat $\left(260^{\circ} \mathrm{C}\right.$ for $\left.60 \mathrm{~s}\right)$ & \\
\hline 3 & Blue stimulation $\left(125^{\circ} \mathrm{C}\right.$ for $\left.40 \mathrm{~s}\right)$ & $\mathrm{L}_{\mathrm{x}}$ & Infrared stimulation $\left(50^{\circ} \mathrm{C}\right.$ for $\left.100 \mathrm{~s}\right)$ & $\mathrm{L}_{\mathrm{x}, \text { IR50 }}$ \\
\hline 4 & - & & Infrared stimulation $\left(225^{\circ} \mathrm{C}\right.$ for $\left.100 \mathrm{~s}\right)$ & $\mathrm{L}_{\mathrm{x}, \mathrm{pIRIR} 225}$ \\
\hline 5 & Test dose & & Test dose & \\
\hline 6 & Cut heat $\left(220^{\circ} \mathrm{C}\right)$ & & Preheat $\left(260^{\circ} \mathrm{C}\right.$ for $\left.60 \mathrm{~s}\right)$ & \\
\hline 7 & Blue stimulation $\left(125^{\circ} \mathrm{C}\right.$ for $\left.40 \mathrm{~s}\right)$ & $\mathrm{T}_{\mathrm{x}}$ & Infrared stimulation $\left(50^{\circ} \mathrm{C}\right.$ for $\left.100 \mathrm{~s}\right)$ & $\mathrm{T}_{\mathrm{x}, \mathrm{IR} 50}$ \\
\hline 8 & - & & Infrared stimulation $\left(225^{\circ} \mathrm{C}\right.$ for $\left.100 \mathrm{~s}\right)$ & $\mathrm{T}_{\mathrm{x}, \mathrm{p} \text { IRIR225 }}$ \\
\hline 9 & Blue stimulation $\left(280^{\circ} \mathrm{C}\right.$ for $\left.40 \mathrm{~s}\right)$ & & Infrared stimulation $\left(290^{\circ} \mathrm{C}\right.$ for $\left.100 \mathrm{~s}\right)$ & \\
\hline 10 & Return to 1 & & Return to 1 & \\
\hline
\end{tabular}

decided to investigate this approach first. A SAR protocol (Murray \& Wintle 2000) was used with a preheat temperature of $260^{\circ} \mathrm{C}$ for $10 \mathrm{~s}$, and a cut-heat of $220^{\circ} \mathrm{C}$. Stimulation was at $125^{\circ} \mathrm{C}$ for $40 \mathrm{~s}$ using blue light. A high-temperature blue light stimulation at $280^{\circ} \mathrm{C}$ was also applied at the end of each cycle to reduce recuperation (Table 2; Murray \& Wintle 2003). The test dose varied between 15 and $40 \%$ of the natural dose estimated in test runs. For calculations, the initial $0.8 \mathrm{~s}$ (the first five channels) of the signal less a background from an adjacent $1.6 \mathrm{~s}$ (channels 11-20) was used. The early background subtraction was chosen to minimize the possible effect of the more difficult to bleach and more thermally unstable medium and slow components; these effects may give rise to both age over- and underestimations (Li \& Li 2006; Pawley et al. 2010). Figure 4 shows a typical dose response curve for sample 098813 , which grows up to a dose of $180 \mathrm{~Gy}$.

As the dose rates to these samples are relatively high for coarse-grained deposits (mean $=2.56 \pm$ $0.13 \mathrm{~Gy} \mathrm{ka}^{-1}, n=16$ ), the natural quartz OSL signal was found to be in saturation for all the samples except the

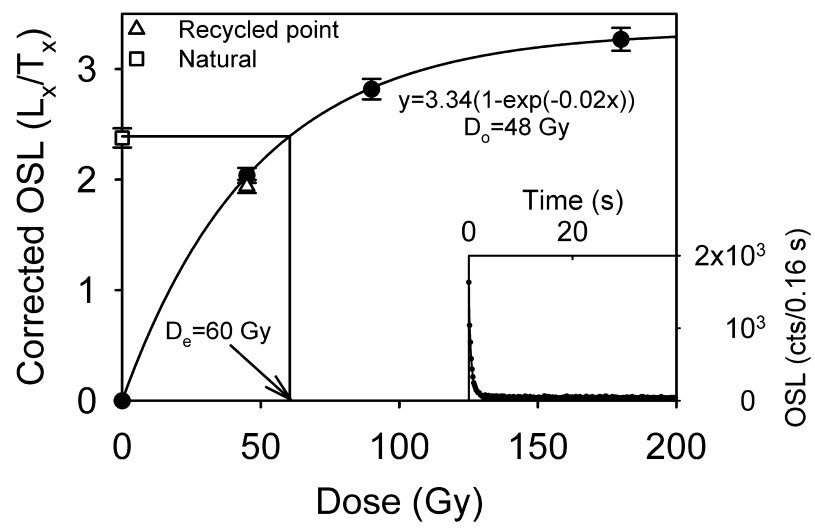

Fig. 4. Typical dose response curve for quartz. Fitting a single exponential growth curve gives a $D_{0}$ value of $48 \mathrm{~Gy}$. The inset shows a typical decay curve. two youngest ones: 098806 and 098813. Fitting a single exponential saturating dose response curve gives a $D_{0}$ value of $\sim 48 \mathrm{~Gy}$, suggesting that quartz cannot be reliably used to estimate doses larger than $\sim 96$ Gy in this case (Wintle \& Murray 2006) (Fig. 4). This is equivalent to an upper age limit to quartz OSL at this site of $\sim 40 \mathrm{ka}$.

The recycling ratio, recuperation, and dose recovery tests were carried out for the two samples 098806 and 098813. The average recycling ratio was $0.99 \pm 0.01$ $(n=17)$ and $0.98 \pm 0.01(n=15)$, respectively, and the average recuperation was $0.21 \pm 0.04(n=17)$ and $0.05 \pm 0.11 \%(n=15)$ of the natural signal. For the dose recovery test the samples were bleached for $100 \mathrm{~s}$ twice using blue LEDs, with a pause of $\sim 3 \mathrm{~h}$ between exposures to allow for any charge trapped in shallow refuge traps (especially that associated with the $110^{\circ} \mathrm{C}$ TL peak) to return to the OSL trap; they were then given doses close to their equivalent doses $\left(D_{e}\right)$. The measured-to-given dose ratio was $1.09 \pm 0.05(n=11)$ for sample 098806 , and $1.02 \pm 0.05(n=11)$ for sample 098813, showing that a known laboratory dose can be recovered within acceptable limits. The resulting OSL ages for these two samples are presented in Table 3.

\section{Post-IR IRSL}

Owing to the saturation of the quartz OSL signal in all samples except the two youngest, we decided to measure the $\mathrm{D}_{\mathrm{e}} \mathrm{s}$ using $\mathrm{K}$-feldspar, because its luminescence signal increases with dose to much higher levels than the standard quartz OSL signal, allowing the dating of older samples, at least in principle (Wallinga et al. 2007; Buylaert et al. 2008b, 2011).

However, K-feldspar usually suffers from athermal (anomalous) fading (Wintle 1973; Spooner 1994), whereby the signal decreases with time faster than expected from a knowledge of the trap depth. It is now broadly accepted that the tunnelling of electrons from thermally stable traps to close-by recombination centres is the most likely cause of this loss of lumines- 


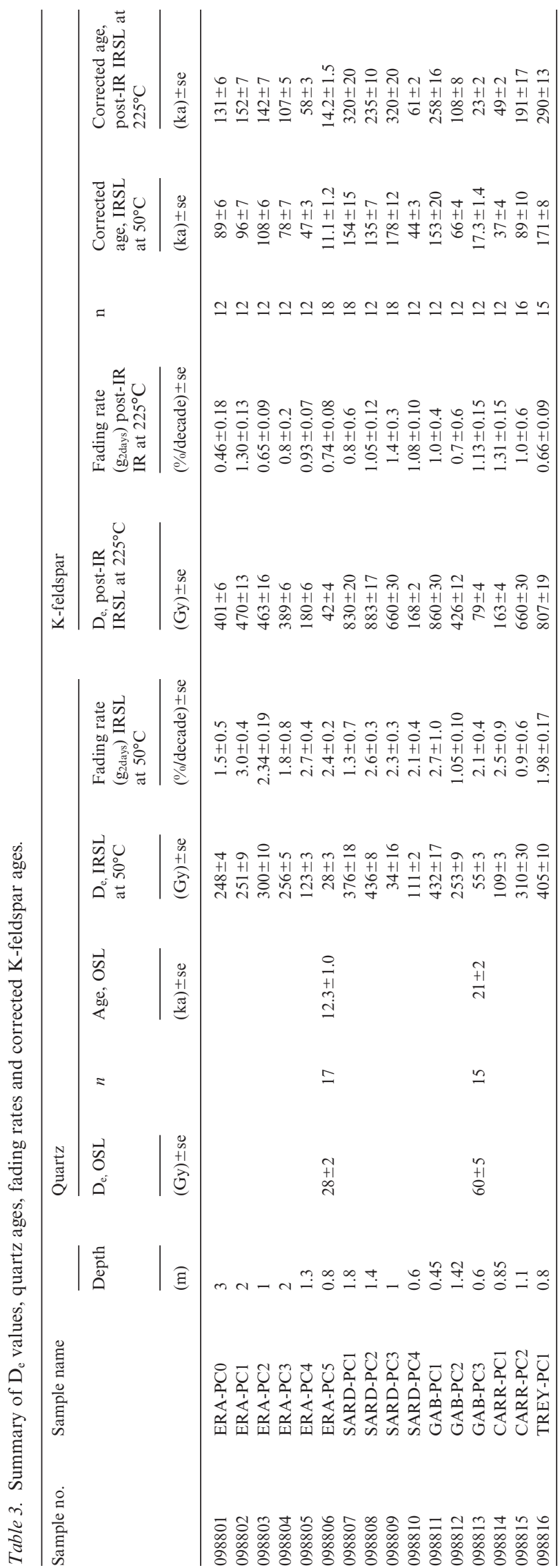

cence signal. The presence of anomalous fading results in age underestimations (Aitken 1985; Huntley \& Lamothe 2001).

Various methods have been proposed for correcting for anomalous fading. For instance, Huntley \& Lamothe (2001) suggested an age-correction model that makes use of the ' $\mathrm{g}$ '-value determined on a laboratory time scale. However, the assumptions involved in the development of their model restrict its use to the low-dose region of the dose response curve (Huntley \& Lamothe 2001). This limitation significantly reduces the effective age range of $\mathrm{K}$-feldspar, although Buylaert et al. (2011) showed that the model might be applicable beyond the linear part of the dose response curve. More recently, Thomsen et al. (2008) showed that the IRSL signal measured at an elevated temperature (e.g. $225^{\circ} \mathrm{C}$ for $100 \mathrm{~s}$ ) after an IR bleach at a low temperature (e.g. $50^{\circ} \mathrm{C}$ for $100 \mathrm{~s}$ ), known as a post-IR IRSL signal, shows a significantly lower laboratory fading rate than the conventional IRSL signal at $50^{\circ} \mathrm{C}$. Buylaert et al. (2009) confirmed that this finding applied to natural signals by using the same post-IR IRSL signal to date K-rich feldspar extracts from various samples, some of them of known (MIS5e) age; they showed that, after correcting for fading, this signal provided accurate ages back to $\sim 120 \mathrm{ka}\left(\sim 200 \mathrm{~Gy}\right.$ uncorrected $\left.\mathrm{D}_{\mathrm{e}}\right)$. Because the fading rates are much lower than those measured at $50^{\circ} \mathrm{C}$, any errors introduced by the correction model are correspondingly smaller. Following these encouraging findings, we decided to try a similar approach for our samples.

$D_{e}$ determination using K-feldspar. - The $\mathrm{D}_{\mathrm{e}}$ was measured using a SAR protocol with a preheat of $260^{\circ} \mathrm{C}$ for $60 \mathrm{~s}$ after both regenerative and test doses. The first IR stimulation at $50^{\circ} \mathrm{C}$ was followed by a second IR stimulation at $225^{\circ} \mathrm{C}$. A high-temperature stimulation at $290^{\circ} \mathrm{C}$ was also given at the end of each SAR cycle as a clean-out. All IR stimulations were carried out for $100 \mathrm{~s}$ (Table 2). The initial $2 \mathrm{~s}$ of stimulation less a background from the last $10 \mathrm{~s}$ was used for all calculations. Test dose values were chosen to be $\sim 25 \%$ of the pIRIR $_{225} D_{\mathrm{e}}$ estimates for all samples after some test runs.

The pIRIR 225 signal was measured in steps 4 and 8 , and the $\mathrm{IR}_{50}$ signal was measured in steps 3 and 7 (Table 2). The typical decay curves given in Fig. 5 show that the pIRIR 225 has a much higher intensity than the $\mathrm{IR}_{50}$, which is in agreement with earlier reports (e.g. Duller \& Bøtter-Jensen 1993; Poolton et al. 2002; Buylaert et al. 2009). However, the similarity of the normalized decay curves shows that the decay rates for the two signals are comparable (inset to Fig. 5). The two dose response curves are also almost identical in shape, but the interpolated naturals give very different $D_{e}$ estimates (Fig. 6). The average ratio of $L_{n} / T_{n}$ from pIRIR 225 to $\mathrm{L}_{\mathrm{n}} / \mathrm{T}_{\mathrm{n}}$ from $\mathrm{IR}_{50}$ is $1.34 \pm 0.01(n=219$, all 


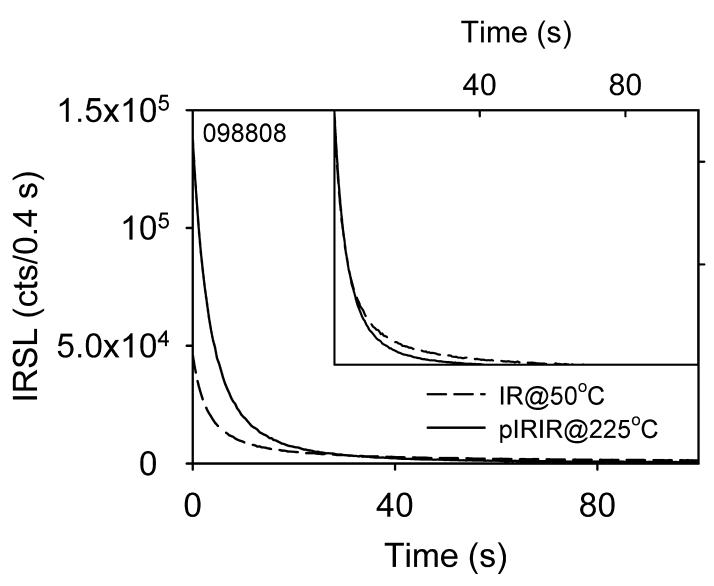

Fig. 5. Typical decay curves for $\mathrm{IR}_{50}$ and pIRIR 225 signals. The inset shows the signals normalized to their highest intensity.

samples), supporting the suggestion that the post-IR IRSL signal fades less in nature (Buylaert et al. 2009). The pIRIR 225 data are well represented by the sum of two exponential functions and give $D_{0}$ values of 335 and $1000 \mathrm{~Gy}$; such a functional form could arise, for example, because of changing competition effects with dose. We assume that it would be unsafe to use light levels of more than $86 \%$ of saturation (corresponding to $\sim 2 \mathrm{D}_{\text {o }}$ for a single exponential) (Wintle \& Murray 2006). Projection of this level on the dose response curve gives a corresponding dose of $\sim 1350$ Gy on the dose axis. This suggests an upper limit to the datable age range of $\sim 390 \mathrm{ka}$ (assuming an average dose rate of $\sim 3.5 \mathrm{~Gy} \mathrm{ka}^{-1}$ typical in the study region).

Recycling ratio, recuperation and dose recovery tests were carried out routinely for all samples as part of testing the applicability of the selected SAR pro-

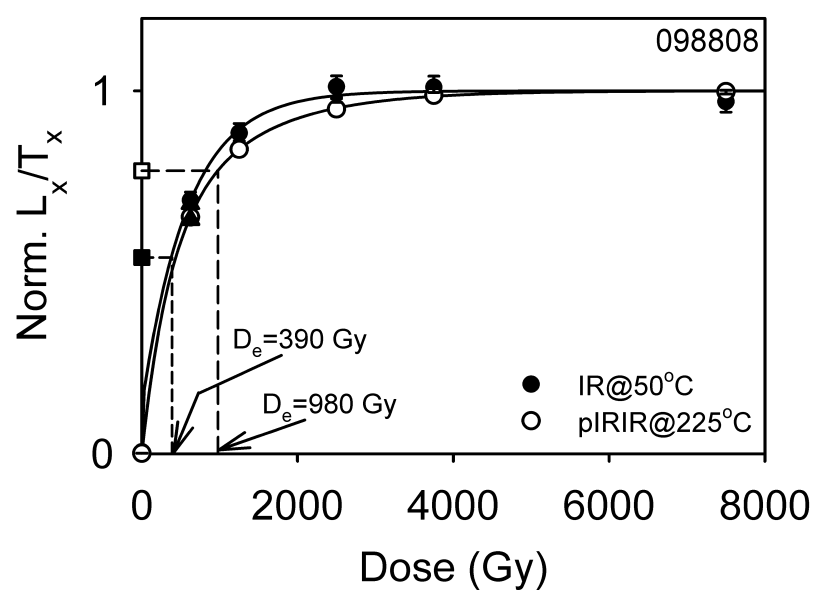

Fig. 6. Normalized dose response curves for $\operatorname{IR}_{50}$ and pIRIR $_{225}$ signals. The sum of two saturating exponential functions used for fitting gives $\mathrm{D}_{\mathrm{o}}$ values of 335 and $1000 \mathrm{~Gy}$.

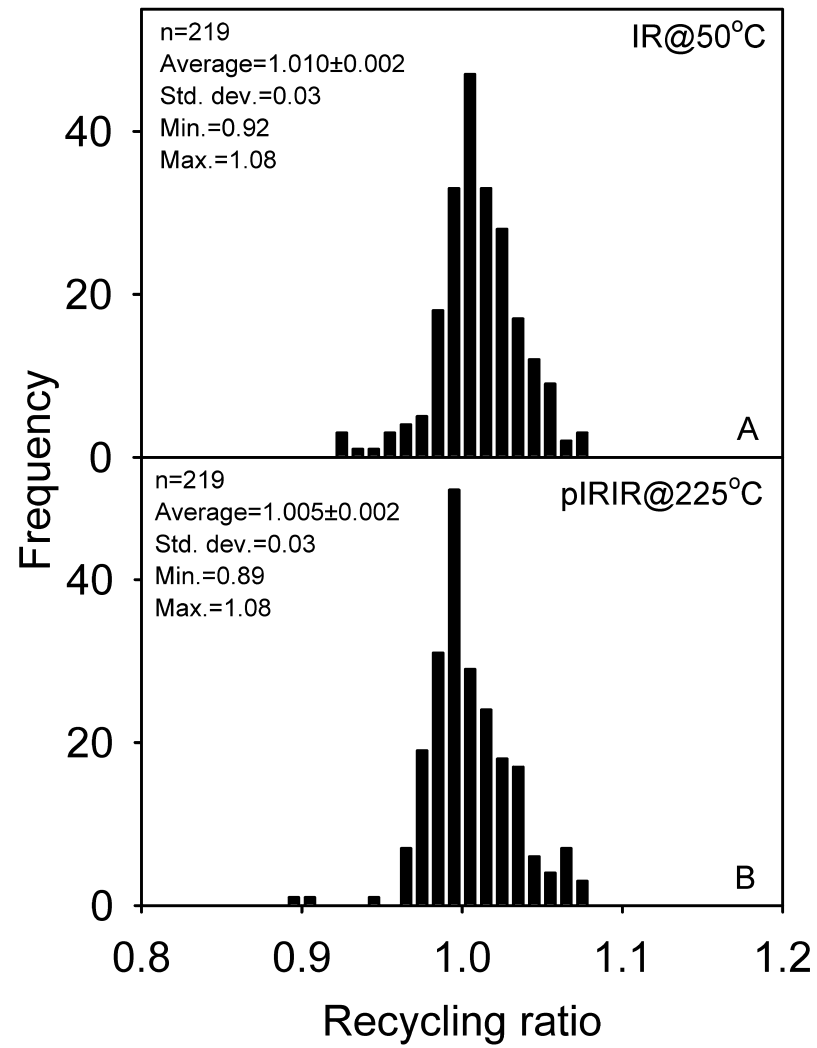

Fig. 7. Distribution of recycling ratios for (A) $I_{50}$ and (B) $p I R I R_{225}$ signals.

tocol. The average recycling ratio is $1.005 \pm 0.001$ and $1.010 \pm 0.002(n=219)$ for $\operatorname{pIRIR}_{225}$ and $\mathrm{IR}_{50}$, respectively (Fig. 7). Recuperation is $0.52 \pm 0.03 \%$ of the natural signal for pIRIR 225 , and $0.30 \pm 0.03 \%$ for $\operatorname{IR}_{50}$. There is no general consensus on the best method of bleaching feldspars prior to a dose recovery test (Wallinga et al. 2000; Buylaert et al. 2009); we chose to bleach all the samples in a Hönle SOL2 solar simulator for $4 \mathrm{~h}$ at a distance of $\sim 80 \mathrm{~cm}$ (to avoid heating the samples). Three aliquots of each sample were then given a dose similar to the $D_{e}$ value measured using pIRIR $_{225}$. Three additional aliquots were also measured to determine the amount of residual doses in the samples after bleaching in the laboratory. Figure 8 presents a summary of the measured doses (less the residual doses) plotted against the given doses for all samples. For both signals, all the ratios lie within $\pm 10 \%$ of a slope of unity, indicating that the SAR protocol performs acceptably in both cases. The mean ratios for $\mathrm{IR}_{50}$ and $\mathrm{pIRIR}_{225}$ signals are $0.94 \pm 0.01$ and $1.00 \pm 0.01(n=48)$, respectively (Fig. 8).

Residual doses. - Figure 9A, B summarizes the $\mathrm{IR}_{50}$ and pIRIR $_{225}$ residual doses measured after bleaching in the laboratory ( $\sim \mathrm{h}$ in the solar simulator). The residual 
doses appear to depend on the corresponding natural doses; that is, the larger the natural doses, the larger the residuals. This observation is reported here for the first time for OSL signals. The intercepts for the linear $\left(\mathrm{IR}_{50}\right)$ and exponential (pIRIR 225 ) curves fitted to data are $0.17 \pm 0.15$ and $0.93 \pm 0.80 \mathrm{~Gy}$, respectively. These intercepts, which cannot definitely be distinguished from zero, correspond to the residual doses present in a fully bleached, modern sample and should be seen as the unbleachable residual doses likely to have been present in all these samples at the time of deposition. However, it is important to realize that these curves do not give information about the completeness of bleaching in nature at the individual sample level, only that there may be some small apparently unbleachable component present. Other researchers have also found difficulty in reducing pIRIR signals to negligible values (e.g. Buylaert et al. 2009; Reimann et al. 2011; Thiel et al. 2011).

The question remains: should the residual doses observed in the laboratory after bleaching be subtracted from the natural doses or not? The difference between the pIRIR 225 and quartz ages for the two youngest samples (Table 3 ) implies that the pIRIR 225 residual dose in nature is $\sim 6$ Gy rather than the $0.93-\mathrm{Gy}$ unbleachable residual discussed above. This 6-Gy residual is significantly smaller than many of the residuals observed after laboratory bleaching (Fig. 9B). There are two possibilities: (i) the residual dose prior to deposition was related to the subsequent burial dose as in Fig. 9B - this seems unlikely - or (ii) the $\sim 6-$ Gy residual doses in nature apply to all samples presumably this reflects some incomplete bleaching

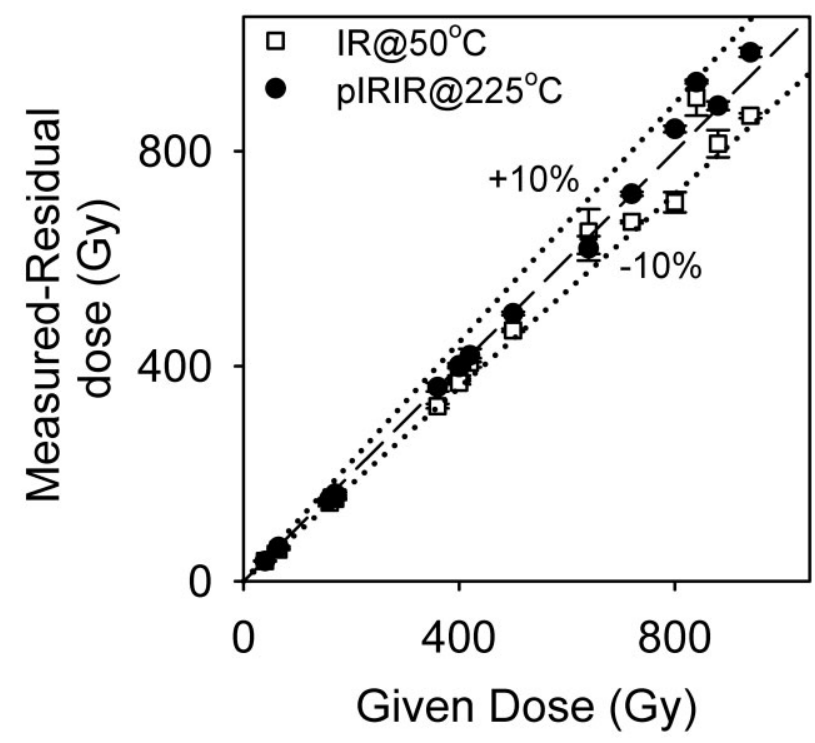

Fig. 8. Dose recovery results for all samples (three aliquots each). The dotted lines show $10 \%$ deviation from unity. The error bars represent one standard error.
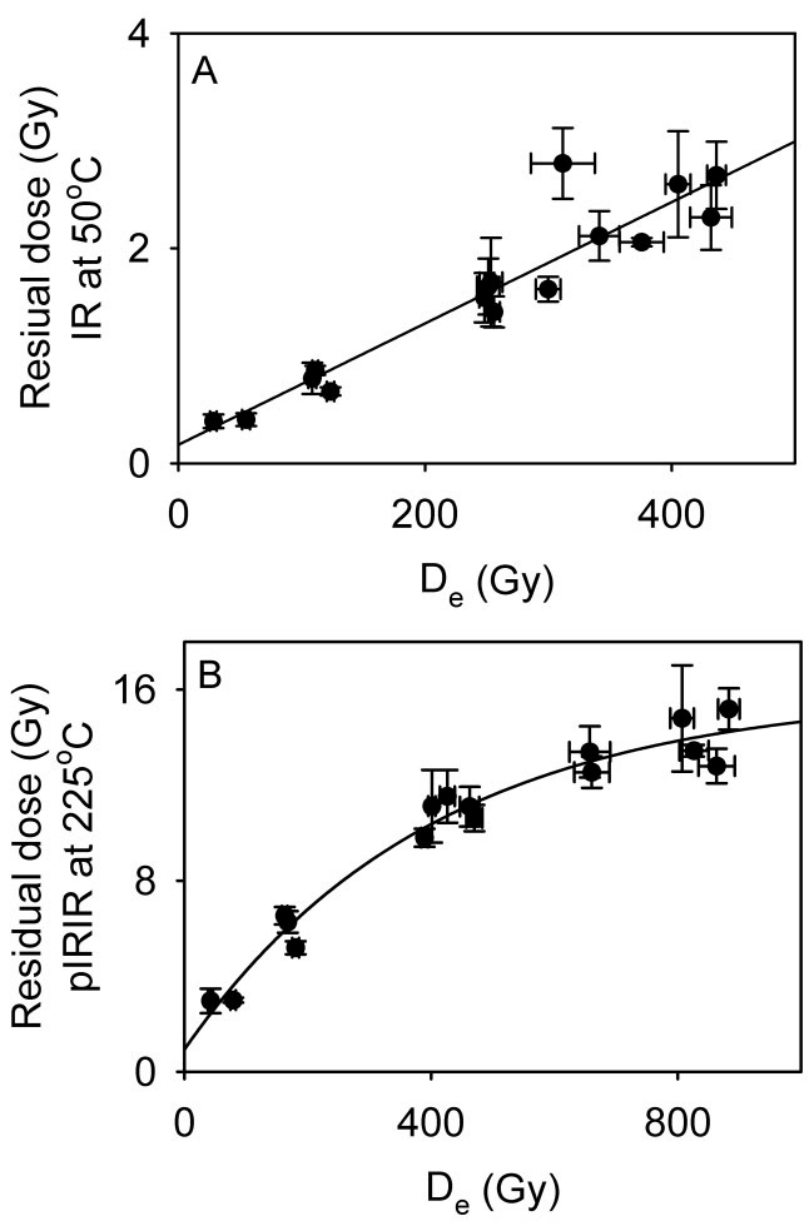

Fig. 9. Residual doses in the samples (three aliquots each) for (A) $\mathrm{IR}_{50}$ and (B) pIRIR 225 signals. The error bars represent one standard error.

in nature of these alluvial samples. Nevertheless, it appears that laboratory bleaching was insufficient to reduce the residual dose to that present at the time of deposition. A natural residual dose of $<10 \mathrm{~Gy}$ is negligible compared with the $D_{e}$ of all the older samples, and so we have not made any residual correction to our ages.

Measurement of anomalous fading. - Anomalous fading is usually quantified by the ' $\mathrm{g}$ '-value, which expresses the fading rate as a percentage of signal lost during a storage period of one decade of time, where the storage periods are expressed as decades relative to the laboratory irradiation time (Aitken 1985: appendix F).

The fading rates were measured using SAR cycles (Table 2) on the same aliquots as used for $\mathrm{D}_{\mathrm{e}}$ determination. Three aliquots were measured to evaluate the ' $\mathrm{g}$ '-value for each sample following Auclair et al. (2003). A regenerative dose of $80 \mathrm{~Gy}$ and a test dose of 40 Gy were used throughout. The ratios of regenerated signals $\left(L_{x}\right)$ to test dose signals $\left(T_{x}\right)$ were measured 


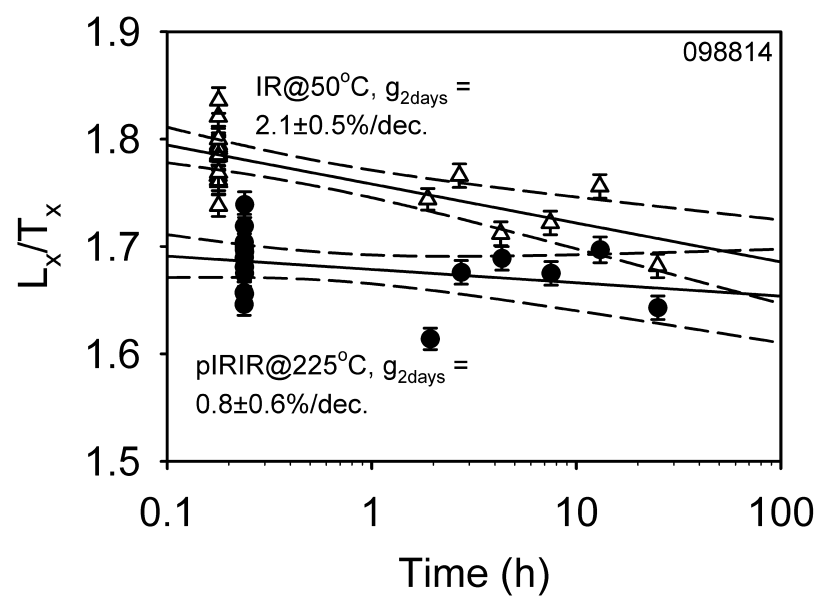

Fig. 10. Typical example of fading rates for $\operatorname{pIRIR}_{225}$ (closed circles) and $\mathrm{IR}_{50}$ (open triangles). Dashed lines indicate $2 \sigma$.

repeatedly, with time delays of $\sim 0.18 \mathrm{~h}\left(\mathrm{IR}_{50}\right)$ and $\sim 0.24 \mathrm{~h}(\mathrm{pIRIR} 225)$ for prompt measurements, and $12 \mathrm{~h}$ for delay measurements. The ' $\mathrm{g}$ '-values were calculated using equation 4 of Huntley \& Lamothe (2001) and normalized to a measurement delay time $\left(t_{c}\right)$ of 2 days after irradiation (Fig. 10). The average $\mathrm{g}_{2 \text { days }}$-value for the pIRIR 225 signal $(0.94 \pm 0.07 \% /$ decade, $n=48)$ is significantly lower than that of the conventional $\mathrm{IR}_{50}$ signal (2.08 $\pm 0.16 \% /$ decade, $\left.n=48\right)$ (Fig. 11$)$; this observation is in agreement with earlier findings for

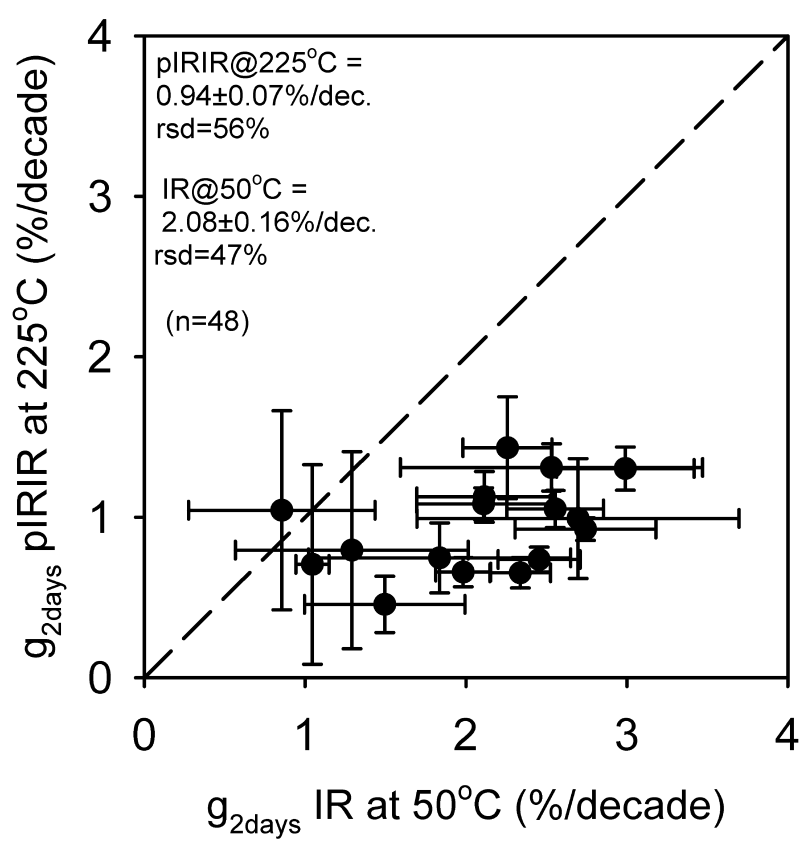

Fig. 11. pIRIR 225 fading rates plotted against $\mathrm{IR}_{50}$ fading rates. Fading rates are averaged per sample (three aliquots per sample). The error bars represent one standard error. coarse-grained K-feldspar (e.g. Thomsen et al. 2008; Buylaert et al. 2009; Alappat et al. 2010).

$\mathrm{D}_{\mathrm{e}} \mathrm{s}, \mathrm{g}_{2 \mathrm{days}}$-values and uncorrected and corrected (following Huntley \& Lamothe 2001) ages for both $\mathrm{IR}_{50}$ and pIRIR 225 are summarized in Table 3.

\section{Discussion}

Correction for fading using the average fading rate for individual samples (three aliquots each) and based on the Huntley \& Lamothe (2001) model changes the pIRIR $_{225}$ feldspar ages by only $\sim 8 \%$; systematic errors in this correction resulting from the fading model are expected to be less important than for the $\mathrm{IR}_{50}$ signals, for which fading corrections are $\sim 17 \%$ (Table 3 ). The quartz ages for the two youngest samples (098806 and 098813) are individually consistent with both the $\mathrm{IR}_{50}$ and the pIRIR 225 ages, although there is a systematic tendency for the $\mathrm{IR}_{50}$ results to underestimate the quartz ages and for the pIRIR 225 results to overestimate. The latter overestimate is consistent with a residual dose of $\sim 6 \mathrm{~Gy}(\sim 2 \mathrm{ka})$; such a residual is small in these two cases and would be negligible in the older samples. The possible underestimate in $\mathrm{IR}_{50}$ ages identified above in the two youngest samples becomes much more pronounced in the older samples (see Table 3). For instance, for samples 098803 and 098804 the underestimate compared with pIRIR 225 is $\sim 30 \%$ at $\sim 110$ and $\sim 140 \mathrm{ka}$, respectively. This is the age range in which Buylaert et al. (2009) were able to demonstrate that the Huntley \& Lamothe (2001) correction model still provided accurate ages, although their dose rates were significantly $(\sim 30 \%)$ lower. The possible underestimate in $\mathrm{IR}_{50}$ ages may suggest that the degree of fading has been underestimated. When considered together with the results of the routine SAR tests, these observations support the reliability of the resulting pIRIR 225 feldspar ages, even in the absence of age control for the older samples.

According to Ortuño et al. (in press), all the luminescence ages (except that for sample 098809, SARD-PC3) are consistent with stratigraphic expectations and provide a chronological framework covering the last 320 ka (see also Fig. 3). Sample 098809 was taken from poorly sorted coarse sand, which presumably was not fully bleached during the short transport distance $(10-20 \mathrm{~m})$ from the adjacent scarp. These ages allow the calculation of slip rates for the various fault branches studied in this work. The rates are approximated by considering the maximum vertical displacement of the best marker layer and its corresponding age in each of the trenches.

For the southernmost fault branch, data from the Era trench are considered (Figs 2, 3). In this trench, a vertical displacement of $\sim 4.7 \mathrm{~m}$ can be inferred from the geometry of the base of the unit $\mathrm{C} 1$ (Fig. 3). This leads to a vertical slip rate of $0.03-0.04 \mathrm{~mm} \mathrm{a}^{-1}$ in this 
part of the fault branch. For the northernmost fault branch, data from the Carrascos-2 trench are used (Figs 2,3). Here, the ground surface is considered as a reference level for the top of the unit $\mathrm{C} 2$, and this gives a minimum vertical slip of $\sim 1.4 \mathrm{~m}$ (Fig. 3). Because the northernmost fault branch is split into two branches in this region, this vertical slip can be assumed to be half of the total slip of the branch at depth, which would be $\sim 2.7 \mathrm{~m}$. Given the age of unit $\mathrm{C} 2$ by sample GABAPC2 (098812) in Gabarrones trench (Fig. 3), a vertical slip rate of $0.02-0.03 \mathrm{~mm} \mathrm{a}^{-1}$ can be estimated for this branch.

The southern termination of the AMF comprises four fault branches, all showing evidence of Quaternary deformation. By extrapolating the slip rates estimated above to the external branches of the fault system (marked in pink in Fig. 2), an approximate minimum vertical slip rate between 0.11 and $0.13 \mathrm{~mm} \mathrm{a}^{-1}$ can be derived for the fault system in this area. These values are consistent with those reported for the other segments of the fault and also for other faults in the region (Silva et al. 1997; Martínez-Díaz et al. 2003; Masana et al. 2004, 2005).

By assuming a total length of $\sim 6 \mathrm{~km}$ for the system and that the whole system might rupture the surface in a single seismic event (Fig. 2), the magnitude of the maximum credible earthquake is $\mathrm{M}_{\mathrm{w}} \approx 6.5$ with a recurrence interval of 10 to $70 \mathrm{ka}$ (see Ortuño et al. in press for details). This is very important new information and is vital for seismic hazard assessment in the region, which was struck by the Lorca earthquake (11th May 2011, $\mathbf{M}_{\mathrm{w}}=5.1$ ), the most damaging earthquake this century in the Iberian Peninsula.

The dose rates at these sites were, in our experience, unusually high. In more typical environments it is likely that ages of at least $\sim 400 \mathrm{ka}$ could be determined. Thus the pIRIR 225 method seems to have the potential to provide a long-term chronology for various aspects of tectonic activity over the past $0.4 \mathrm{Ma}$. This is a considerable improvement over the age range available in most of the previous studies (using quartz) and also compared with the few studies that have used a lowtemperature fading IRSL signal from feldspar (Fattahi et al. 2007; Porat et al., 2009). Although we cannot be completely confident of the accuracy of our older ages (because of the absence of the age control and the small but finite fading correction), we are confident that this method will demonstrate its potentially wide application to tectonic studies in the near future.

\section{Conclusions}

The ages of Pleistocene alluvial units disturbed by the AMF have been determined using the IRIR $_{225}$ signal from $\mathrm{K}$-feldspar. Owing to the average high dose rate of $2.6 \mathrm{~Gy} \mathrm{ka}^{-1}$, quartz OSL dating had an upper age limit of $\sim 40 \mathrm{ka}$, and this allowed the dating only of the youngest beds of the sedimentary succession. However, the K-feldspar pIRIR 225 signal was able to provide age estimates for the older samples; these ages are all in accordance with the stratigraphy, except for one poorly sorted alluvial sample.

Our results show that the pIRIR 225 signal has a lower fading rate $(0.9 \% /$ decade $)$ than the conventional $\mathrm{IR}_{50}$ signal measured as part of the post-IR IRSL SAR sequence $(2.1 \% /$ decade) and permits dating sediments as old as $\sim 320 \mathrm{ka}$. Quartz is more readily bleached than feldspar, especially in these alluvial sediments, and so the agreement between quartz OSL ages and pIRIR 225 ages for the two youngest samples indicates that the feldspar in these two samples must have been fully bleached. We conclude that there is no evidence for incomplete bleaching in feldspar in these materials, except in the case of one alluvial sample. Although the residual dose curves do not give information about the completeness of bleaching in nature, we can conclude that there is probably a small unbleachable component in both the $\mathrm{IR}_{50}$ and pIRIR 225 signals; for these samples the unbleachable residual amounts to 0.17 and $0.93 \mathrm{~Gy}$, respectively. Furthermore it is remarkable that $4 \mathrm{~h}$ in a solar simulator was insufficient to fully bleach these feldspar signals; in the case of the youngest two samples at least, natural bleaching before deposition was probably more complete.

Unfortunately, there was no independent age control available to confirm the reliability of this new protocol for our older samples. Nevertheless, the low fading rates for the pIRIR 225 signal make any age correction small, and so any remaining age underestimation as a result of inadequate fading correction is probably small.

Finally, the ages of the nine alluvial fan units along the piedmont of the Las Estancias range have been usefully constrained by our post-IR IRSL dating. Because these units are deformed by the AMF, their ages allowed us to assess the likely return period, and thus the seismic hazard associated with this active fault.

Acknowledgements. - This work was funded by the Spanish Ministerio de Educación y Ciencia (the EVENT project, CGL2006-12861C02-01/BTE) and the Consolider-Ingenio 201045 program (CSD2006-0004 'Topo-Iberia') and by the PTDC/CTE-GIN/66283/ 2006 project approved by the FCT and co-funded by the FEDER. The authors would like to thank two anonymous reviewers for their careful reading of the manuscript and for constructive comments.

\section{References}

Aitken, M. J. 1985: Thermoluminescence Dating. 359 pp. Academic Press, London.

Alappat, L., Tsukamoto, S., Singh, P., Srikanth, D., Ramesh, R. \& Frechen, M. 2010: Chronology of Cauvery delta sediments from shallow subsurface cores using elevated-temperature post-IR IRSL fating of feldspar. Geochronometria 37, 37-47.

Amit, R., Harrison, J. B. J., Enzel,Y. \& Porat, N. 1996: Soils as a tool for estimating ages of Quaternary fault scarps in a hyperarid 
environment - the southern Arava valley, the Dead Sea Rift, Israel. Catena 28, 21-45.

Auclair, M., Lamothe, M. \& Huot, S. 2003: Measurement of anomalous fading for feldspar IRSL using SAR. Radiation Measurements 37, 487-492.

Berger, G. W., Sawyer, T. L. \& Unruh, J. R. 2010: Single- and multigrain luminescence dating of sediments related to the Greenville fault, eastern San Francisco Bay area, California. Bulletin of the Seismological Society of America 100, 1051-1072.

Bøtter-Jensen, L., Thomsen K. J. \& Jain M. 2010: Review of optically stimulated luminescence (OSL) instrumental developments for retrospective dosimetry. Radiation Measurements 45, 253-257.

Buylaert, J.-P., Huot, S., Van den Haute, P. \& Murray, A. S. 2011: Infrared stimulated luminescence dating of an Eemian (MIS 5e) site in Denmark using K-feldspar. Boreas 40, 46-56.

Buylaert, J.-P., Murray, A. S. \& Huot, S. 2008b: Optical dating of an Eemian site in Northern Russia using K-feldspar. Radiation Measurements 43, 715-720.

Buylaert J.-P., Murray, A. S., Thomsen, K. J. \& Jain, M. 2009: Testing the potential of an elevated temperature IRSL signal from K-feldspar. Radiation Measurements 44, 560-565.

Buylaert, J.-P., Murray A. S., Vandenberghe, D., Vriend, M., De Corte, F. \& Van den Haute, P. 2008a: Optical dating of Chinese loess using sand-sized quartz: Establishing a time frame for Late Pleistocene climate changes in the western part of the Chinese Loess Plateau. Quaternary Geochronology 3, 99-113.

Chen, Y. G., Chen, Y. W., Chen, W. S., Zhang, J. F., Zhao, H., Zhou, L. P. \& Li, S. H. 2003b: Preliminary results of long-term slip rates of 1999 earthquake fault by luminescence and radiocarbon dating. Quaternary Science Reviews 22, 1213-1221.

Chen, Y. W., Chen, Y. G., Murray, A. S., Liu, T. K. \& Lai, T. C. 2003a: Luminescence dating of neotectonic activity on the southwestern coastal plain, Taiwan. Quaternary Science Reviews 22, $1223-1229$.

Chen, Y. W., Chen, Y. G., Murray, A. S., Watanuki, T., Chen, W. S., Yang, C. C. B., Liu, T. K. \& Lin, C. W. 2009: Long-term crustal movement caused by the Chiuchiungkeng Fault in southwestern Taiwan: Constraints from luminescence dating. Quaternary International 199, 15-24.

Cheong, C. S., Hong, D. G., Lee, K. S., Kim, J. W., Choi, J. H., Murray, A. S., Chwae, U., Im, C. B., Chang, C. J. \& Chang, H. W. 2003: Determination of slip rate by optical dating of fluvial deposits from the Wangsan fault, SE Korea. Quaternary Science Reviews $22,1207-1211$

Crone, A. J., De Martini, P. M., Machette, M. N., Okumura, K. \& Prescott, J. R. 2003: Paleoseismicity of two historically quiescent faults in Australia: implications for fault behavior in stable continental regions. Bulletin of the Seismological Society of America 93, 1913-1934.

Duller, G. A. T. \& Bøtter-Jensen, L. 1993: Luminescence from potassium feldspars stimulated by infrared and green light. Radiation Protection Dosimetry 47, 683-688.

Fattahi, M. \& Walker, R. 2007: Luminescence dating of the last earthquake of the Sabzevar thrust fault, NE Iran. Quaternary Geochronology 2, 284-289.

Fattahi, M., Nazari, H., Bateman, M. D., Meyer, B., Sébrier, M., Talebian, M., Le Dortz, K., Foroutan, M., Ahmadi Givi, F. \& Ghorashi, M. 2010: Refining the OSL age of the last earthquake on the Dehshir fault, Central Iran. Quaternary Geochronology 5, 286-292.

Fattahi, M., Walker, R., Hollingsworth, J., Bahroudi, A., Nazari, H., Talebian, M., Armitage, S. \& Stokes, S. 2006a: Holocene slip-rate on the Sabzevar thrust fault, NE Iran, determined using optically stimulated luminescence (OSL). Earth and Planetary Science Letters 245, 673-684

Fattahi, M., Walker, R., Khatib, M. M., Dolati, A. \& Bahroudi, A. 2006b: Slip-rate estimates and past earthquakes on the Doruneh fault, eastern Iran. Geophysical Journal International 168, 691709

Haibing, Li., Van der Woerd, J., Tapponnier, P., Klinger, Y., Xuexiang, Q., Jingsui, Y. \& Yintang, Z. 2005: Slip rate on the Kunlun fault at Hongshui Gou, and recurrence time of great events comparable to the 14/11/2001, $\mathrm{M}_{\mathrm{w}} \sim 7.9$ Kokoxili earthquake. Earth and Planetary Science Letters 237, 285-299.

Huntley, D. J. \& Baril, M. R. 1997: The K content of the K-feldspars being measured in optical dating or in thermoluminescence dating. Ancient TL 15, 11-13.

Huntley, D. J. \& Hancock, R. G. V. 2001: The Rb contents of the $\mathrm{K}$-feldspar grains being measured in optical dating. Ancient TL 19, 43-46.

Huntley, D. J. \& Lamothe, M. 2001: Ubiquity of anomalous fading in $\mathrm{K}$-feldspars and the measurement and correction for it in optical dating. Canadian Journal of Earth Sciences 38, 1093-1106.

Le Dortz, K., Meyer, B., Sébrier, M., Nazari, H., Braucher, R., Fattahi, M., Benedetti, L., Foroutan, M., Siame, L., Bourlès, D., Talebian, M., Bateman, M. D. \& Ghoraishi, M. 2009: Holocene right-slip rate determined by cosmogenic and OSL dating on the Anar fault, Central Iran. Geophysical Journal International 179, 700-710.

Li, B. \& Li, S.-H. 2006: Comparison of $D_{e}$ estimates using the fast component and the medium component of quartz OSL. Radiation Measurements 41, 125-136.

Martínez-Díaz, J. J. 1998: Neotectónica y tectónica activa del sector Centro-occidental de la región de Murcia y sur de Almería (Cordillera Bética- España). Ph.D. thesis, Universidad Complutense de Madrid, $466 \mathrm{pp}$.

Martínez-Díaz, J. J., Masana, E., Hernández-Enrile, J. L. \& Santanach, P. 2001: Evidence for coseismic events of recurrent prehistoric deformation along the Alhama de Murcia fault, southeastern Spain. Acta Geológica Hispánica 36, 315-327.

Martínez-Díaz, J. J., Masana, E., Hernández-Enrile, J. L. \& Santanach, P. 2003: Effects of repeated paleoearthquakes on the Alhama de Murcia Fault (Betic Cordillera, Spain) on the Quaternary evolution of an alluvial fan system. Annales Geophysicae 46, 775792

Masana, E., Martínez-Díaz, J. J., Hernández-Enrile, J. L. \& Santanach, P. 2004: The Alhama de Murcia fault (SE Spain), a seismogenic fault in a diffuse plate boundary: Seismotectonic implications for the Ibero-Magrebian region. Journal of Geophysical Research 109, B01301.

Masana, E., Pallàs, R., Perea, H., Ortuño, M., Martínez-Díaz, J. J., García-Meléndez, E. \& Santanach, P. 2005: Large Holocene morphogenic earthquakes along the Albox fault, Betic Cordillera, Spain. Journal of Geodynamics 40, 119-133.

Mathew, G., Singhvi, A. K. \& Karanth, R. V. 2006: Luminescence chronometry and geomorphic evidence of active fold growth along the Kachchh Mainland Fault (KMF), Kachchh, India: Seismotectonic implications. Tectonophysics 422, 71-87.

Mejdahl, V. 1987: Internal radioactivity in quartz and feldspar grains. Ancient TL 5, 10-17.

Murray, A. S. \& Olley, J. M. 2002: Precision and accuracy in the optically stimulated luminescence dating of sedimentary quartz: a status review. Geochronometria 21, 1-16.

Murray, A. S. \& Wintle, A. G. 2000: Luminescence dating of quartz using an improved single-aliquot regenerative-dose protocol. Radiation Measurements 32, 57-73.

Murray, A. S. \& Wintle, A. G. 2003: The single aliquot regenerative dose protocol: potential for improvements in reliability. Radiation Measurements 37, 377-381.

Murray, A. S., Marten, R., Johnston, A. \& Martin, P. 1987: Analysis for naturally occurring radionuclides at environmental concentrations by gamma spectrometry. Journal of Radioanalytical and Nuclear Chemistry 115, 263-288.

Nazari, H., Fattahi, M., Meyer, B., Sébrier, M., Talebian, M., Foroutan, M., Le Dortz, K., Bateman, M. D. \& Ghorashi, M. 2009: First evidence for large earthquakes on the Deshir Fault, Central Iran Plateau. Terra Nova 21, 417-426.

Nissen, E., Walker, R. T., Bayasgalan, A., Carter, A., Fattahi, M., Molor, E., Schnabel, C., West, J. A. \& Xu, S. 2009: The late Quaternary slip-rate of the Har-Us-Nuur fault (Mongolian Altai) from cosmogenic ${ }^{10} \mathrm{Be}$ and luminescence dating. Earth and Planetary Science Letters 286, 467-478.

Olley, J., Murray, A. S. \& Roberts, R. G. 1996: The effects of disequilibria in the uranium and thorium decay chains on the burial 
dose rates in fluvial sediments. Quaternary Science Reviews 15, 751-760.

Ortuño, M., Masana, E., García-Meléndez, E., Martínez-Díaz, J., Štěpančíková P., Cunha, P. P., Sohbati, R., Canora, C., Buylaert, J.-P., Murray A. S. In press: An exceptionally long paleoseismic record of a slow-moving fault: the Alhama de Murcia fault (Eastern Betic Shear Zone, Spain). Geological Society of America Bulletin.

Pawley, S. M., Toms, P., Armitage, S. J. \& Rose, J. 2010: Quartz luminescence dating of Anglian Stage (MIS 12) fluvial sediments: Comparison of SAR age estimates to the terrace chronology of the Middle Thames valley, UK. Quaternary Geochronology 5, 569582.

Poolton, N. R. J., Ozanyan, K. B., Wallinga, J., Murray, A. S. \& Bøtter-Jensen, L. 2002: Electrons in feldspar II: a consideration of the influence of the conduction band-tail states on luminescence processes. Physics and Chemistry of Minerals 29, 217-225.

Porat, N., Amit, R., Zilberman, E. \& Enzelt, Y. 1997: Luminescence dating of fault-related alluvial fan sediments in the southern Arava valley, Israel. Quaternary Science Reviews (Quaternary Geochronology) 16, 397-402.

Porat, N., Duller, G. A. T., Amit, R., Zilberman, E. \& Enzel, Y. 2009: Recent faulting in the southern Arava, Dead Sea Transform: Evidence from single grain luminescence dating. Quaternary International 199, 34-44.

Prescott, J. R. \& Hutton, J. T. 1994: Cosmic ray contributions to dose rates for luminescence and ESR dating: large depths and long-term variations. Radiation Measurements 23, 497-500.

Quigley, M. C., Cupper, M. L. \& Sandiford, M. 2006. Quaternary faults of south-central Australia: palaeoseismicity, slip rates and origin. Australian Journal of Earth Sciences 53, 285-301.

Reimann, T., Tsukamoto, S., Naumann, M. \& Frechen, M. 2011: The potential of using K-rich feldspars for optical dating of young coastal sediments - A test case from Darss-Zingst peninsula (southern Baltic Sea coast). Quaternary Geochronology 6, 207-222.

Silva, P. 1994: Evolución geodinámica de la Depresión del Guadalentín desde Mioceno Superior hasta la actualidad: Neotectónica y Geomorfología. Ph.D. thesis, Universidad Complutense de Madrid, $642 \mathrm{pp}$.
Silva, P. G., Goy, J. L., Zazo, C. \& Bardají, T. 2003: Fault-generated mountain fronts in southeast Spain: geomorphologic assessment of tectonic and seismic activity. Geomorphology 50, 203-225.

Silva, P. G., Goy, J. L., Zazo, C., Lario, J. \& Bardají, T. 1997: Paleoseismic indications along 'aseismic' fault segments in the Guadalentín Depression (SE Spain). Journal of Geodynamics 24, $105-115$.

Spooner, N. A. 1994: The anomalous fading of infrared-stimulated luminescence from feldspars. Radiation Measurements 23, 625632.

Thakur, V. C., Pandey, A. K. \& Suresh, N. 2006: Late QuaternaryHolocene evolution of Dun structure and the Himalayan Frontal Fault zone of the Garhwal Sub-Himalaya, NW India. Journal of Asian Earth Sciences 29, 305-319.

Thiel, C., Buylaert, J. P., Murray, A. S., Terhorst, B., Hofer, I., Tsukamoto, S. \& Frechen, M. 2011: Luminescence dating of the Stratzing loess profile (Austria) - Testing the potential of an elevated temperature post-IR IRSL protocol. Quaternary International 234, 23-31.

Thomsen K. J., Murray, A. S., Jain, M. \& Bøtter-Jensen, L. 2008: Laboratory fading rates of various luminescence signals from feldspar-rich sediment extracts. Radiation Measurements 43, 1474 1486.

Wallinga, J., Bos, A. J. J., Dorenbos, P., Murray, A. S. \& Schokker, J. 2007: A test case for anomalous fading correction in IRSL dating. Quaternary Geochronology 2, 216-221.

Wallinga, J., Murray, A. S. \& Duller, G. A. T. 2000: Underestimation of equivalent dose in single-aliquot optical dating of feldspars caused by preheating. Radiation Measurements 32, 691-695.

Wintle, A. G. 1973: Anomalous fading of thermoluminescence in mineral samples. Nature 245, 143-144.

Wintle, A. G. \& Murray, A. S. 2006: A review of quartz optically stimulated luminescence characteristics and their relevance in single-aliquot regeneration dating protocols. Radiation Measurements 41, 369-391.

Yanchou, L., Prescott, J. R., Hua, Z., Jie, C. \& Lanying, W. 2002: Optical dating of colluvial deposits from Xiyangfang, China, and the relation to palaeo-earthquake events. Quaternary Science Reviews 21, 1087-1097.

Corrections added after online publication January 2012: The Reference Ortuño et al. (in press) was updated after Early View publication of this paper, at the author's request to revise the author list and title in the light of changes made whilst in press. The expression '( $n=48)$ ' was added on p. 8 , line 4 from the end of the right column. 